\title{
Cytochalasins from Xylaria sp. CFL5, an Endophytic Fungus of Cephalotaxus fortunei
}

\author{
Kai-Liang Ma ${ }^{1} \cdot$ Shi-Hui Dong ${ }^{1} \cdot$ Hang-Ying $\mathrm{Li}^{1} \cdot$ Wen-Jun Wei ${ }^{1} \cdot$ Yong-Qiang $\mathrm{Tu}^{1} \cdot \mathrm{Kun} \mathrm{Gao}^{1}$
}

Received: 24 September 2020 / Accepted: 26 October 2020 / Published online: 4 November 2020

(c) The Author(s) 2020

\begin{abstract}
Three previously undescribed cytochalasins, named xylariasins A-C (1-3), together with six known ones (4-9) were isolated from Xylaria sp. CFL5, an endophytic fungus of Cephalotaxus fortunei. The chemical structures of all new compounds were elucidated on the basis of extensive spectroscopic data analyses and electronic circular dichroism calculation, as well as optical rotation calculation. Biological activities of compounds 1, 4-9 were evaluated, including cytotoxic, LAG3/MHC II binding inhibition and LAG3/FGL1 binding inhibition activities. Compounds $\mathbf{6}$ and $\mathbf{9}$ possessed cytotoxicity against AGS cells at $5 \mu \mathrm{M}$, with inhibition rates of $94 \%$ and $64 \%$, respectively. In addition, all tested isolates, except compound $\mathbf{6}$, exhibited obvious inhibitory activity against the interaction of both LAG3/MHC II and LAG3/FGL1. Compounds 1, 5, 7, and $\mathbf{8}$ inhibited LAG3/MHC II with $\mathrm{IC}_{50}$ values ranging from 2.37 to $4.74 \mu \mathrm{M}$. Meanwhile, the $\mathrm{IC}_{50}$ values of compounds $\mathbf{1}, \mathbf{7}$, and $\mathbf{8}$ against LAG3/FGL1 were $11.78,4.39$, and $7.45 \mu \mathrm{M}$, respectively.
\end{abstract}

Electronic supplementary material The online version of this article (https://doi.org/10.1007/s13659-020-00279-5) contains supplementary material, which is available to authorized users.

Kun Gao

npchem@1zu.edu.cn

1 State Key Laboratory of Applied Organic Chemistry, College of Chemistry and Chemical Engineering, Lanzhou

University, Lanzhou 730000, People's Republic of China 


\section{Graphic Abstract}

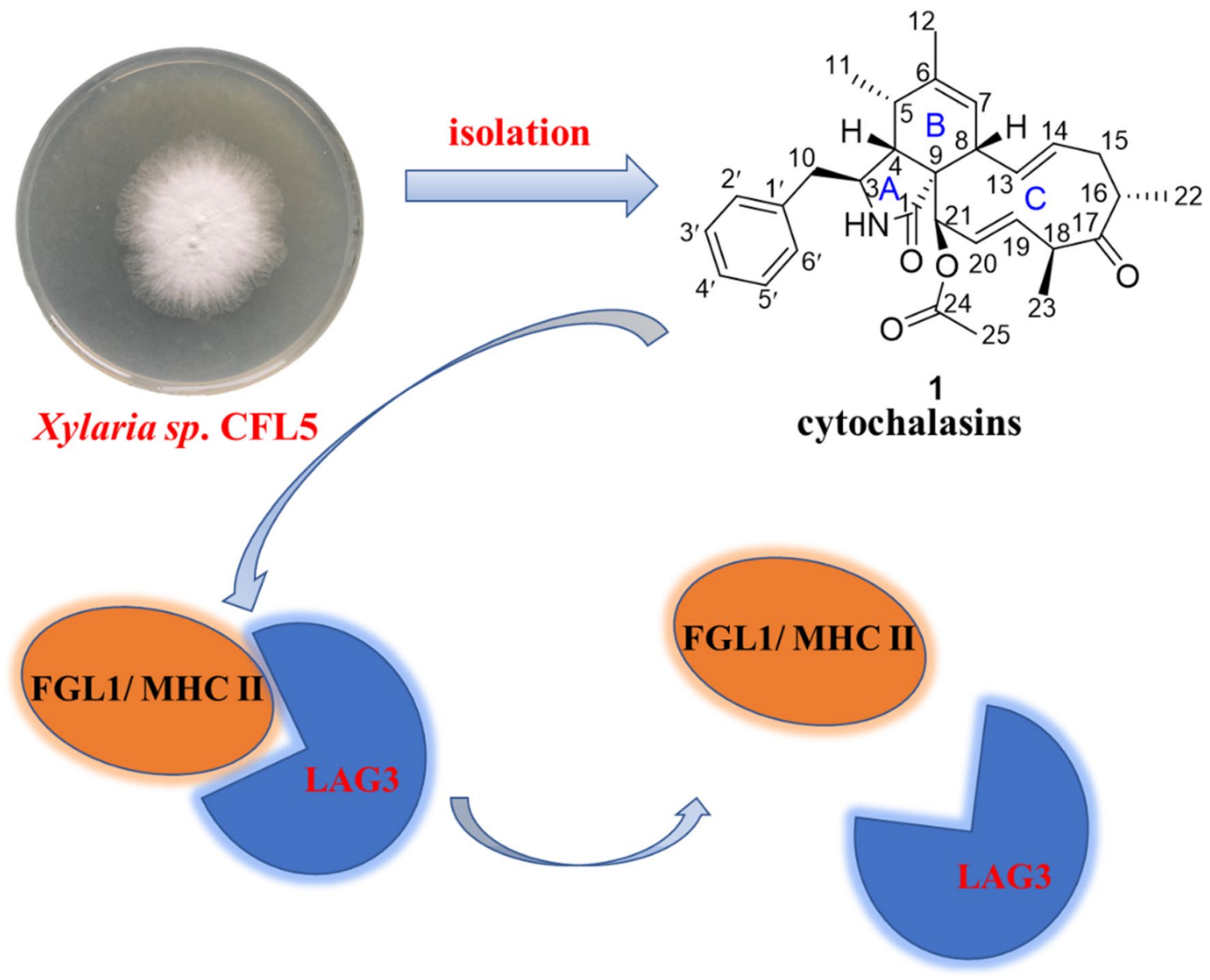

Keywords Cytochalasin · Xylaria sp. · Cephalotaxus fortunei $\cdot$ LAG3/MHC II binding inhibition · LAG3/FGL1 binding inhibition

\section{Introduction}

Cytochalasins, a family of fungal metabolites, represented the hybrid formed by a phenylalanine and a polyketide moiety, which possessed unique chemical structures and various biological activities $[1,2]$. It was reported that phenylalanine-derived cytochalasans were mostly isolated from the fungi of genera including Xylaria [3], Phomopsis [4], Phoma [5], Arthrinium [6], Aspergillus [7, 8]. Biological studies have revealed these compounds occupied antibacterial [9], cytotoxic [10], anti-HIV [8], phytotoxic [3], and NO inhibitory activities [11].

Xylaria was the largest genus of the family Xylariaceae, and members were widespread on the earth [12]. In the traditional view for this genus, they were saprotrophic fungi usually appeared on deadwood, participated in the decomposition of organic waste, even destructed the growth of plants. Since the fact that members of this genus occur ubiquitously as endophytes of vascular plant has been illuminated, not only Xylaria, but the entire Xylariaceae seemed to play an important role in ecology [13]. Previous phytochemical studies on the secondary metabolites of Xylaria resulted in the discovery of various compounds with several distinct types of several bioactivities, such as cytochalasin E with phytotoxicity [14] and nigriterpene C possessing anti-inflammatory effects [15], which highlighted the potential of the fungi from this genus as rich sources of natural products with novel chemical structures and valuable bioactivities.

Harringtonin and homobarringtonie from Cephalotaxus fortunei had been made numerous biological activity evaluation and formal syntheses works in the past several years [16-18], which also attracted our interests to the secondary metabolites of the endophytic fungi from this plant. A strain of Xylaria sp. CFL5 from C. fortunei was incubated in rice 
mediums, a phytochemical investigation resulted in the discovery of nine cytochalasins (1-9). After comprehensive structural characterization, including spectroscopic analysis, calculated optical rotation, and calculated electronic circular dichroism, xylariasins A-C (1-3) were identified to possess undescribed structures.

LAG3 (Lymphocyte-activation gene 3) was mainly expressed in activated $\mathrm{T}$ and natural killer (NK) cells and was identified as a marker for the activation of $\mathrm{CD}^{+}$and $\mathrm{CD} 8^{+} \mathrm{T}$ cells $[19,20]$. After bound with the cognate ligands, it could be activated to inhibit the proliferation and activation of $\mathrm{CD}^{+}$and $\mathrm{CD} 8^{+} \mathrm{T}$ cells, enhance the inhibitory activity of regulatory $\mathrm{T}$ cells (Treg), and thereby promote the immune escape of tumor cells [21]. MHC II (major histocompatibility complex II) was was believed to be a typical ligand of LAG3 in a long time [22, 23]. However, whether MHC II solely involved in the inhibitory effects of LAG3 or not was controversial. Research workers evidenced that FGL1, a secreted protein from liver cells, was a new LAG3 functional ligand independent of MHC II in 2018 [24]. The discovery revealed a novel immune escape mechanism and provided a guidance for the design of cancer immunotherapy. Collectively, drugs acting on the pathways of either LAG3/MHC II or LAG3/FGL1 could play a role in the cancer therapy. There were only 30 anti-LAG3 monoclonal antibodies in research and few small molecule inhibitors reported [25, 26]. It could provide new lead compounds for cancer immunotherapy and improve the cure rate of cancer through the development of small molecule inhibitors that inhibit the binding of LAG3 with MHC II and the binding of LAG3 with FGL1. For these causes, we evaluated the inhibitory effects of cytochalasins $(\mathbf{1}, \mathbf{4 - 9})$ from Xylaria sp. CFL5 on the interactions of LAG3/MHC II and LAG3/FGL1. The results showed that most isolates, except $\mathbf{6}$, exhibited obvious inhibitory activity against the interaction of both LAG3/ MHC II and LAG3/FGL1. More specifically, 1, 5, 7, and 8 inhibited LAG3/MHC II with $\mathrm{IC}_{50}$ values ranging from 2.37 to $4.74 \mu \mathrm{M}$, and the $\mathrm{IC}_{50}$ values of $\mathbf{1 ,} \mathbf{7}$, and $\mathbf{8}$ against LAG3/FGL1 were $11.78,4.39$, and $7.45 \mu \mathrm{M}$, respectively. This was the first report of cytochalasins exhibiting the inhibitory activity against the interaction of LAG3 and MHC II, or LAG3 and FGL1, which underscored the potential of cytochalasin derivatives as anticancer immunosuppressants.

\section{Results and Discussion}

\subsection{Isolation and Structure Elucidation}

The strain of Xylaria sp. CFL5 was inoculated on rice mediums and cultured at $28{ }^{\circ} \mathrm{C}$ for 20 days. Utilizing macroporous resin HP-20, silica gel column chromatography, and semi-preparative HPLC, the investigation of the EtOAc extract of the mediums provided three new $(\mathbf{1}-\mathbf{3})$ and six published (4-9) cytochalasins (Fig. 1). The structures and stereochemistry of these isolates were elucidated on the basis of spectroscopic analysis, optical rotation, and circular dichroism (CD) analysis and comparison with the data in the literature.

Compound $\mathbf{1}$ was isolated as a white powder. Its molecular formula was determined as $\mathrm{C}_{30} \mathrm{H}_{37} \mathrm{NO}_{4}$ according to an $[\mathrm{M}+\mathrm{H}]^{+}$ion peak at $\mathrm{m} / z 476.2793$ (calcd 476.2795) in the HRESIMS spectrum, showing 13 indices of hydrogen deficiency (IOHDs). The characteristic absorptions at 1743 and $1703 \mathrm{~cm}^{-1}$ for carbonyl groups, as well as the bands at $3324 \mathrm{~cm}^{-1}$ for amino groups in its IR spectrum were observed. The ${ }^{1} \mathrm{H},{ }^{13} \mathrm{C}$ NMR, and HSQC spectra for compound 1 revealed three methyl doublets at $\left(\delta_{\mathrm{H}} 1.10\right.$, $\left.J=7.6 \mathrm{~Hz} ; \delta_{\mathrm{C}} 14.2\right),\left(\delta_{\mathrm{H}} 1.15, J=6.8 \mathrm{~Hz} ; \delta_{\mathrm{C}} 19.1\right)$, and $\left(\delta_{\mathrm{H}} 1.22, J=7.2 \mathrm{~Hz} ; \delta_{\mathrm{C}} 16.3\right)$, two methyl singlets at $\left(\delta_{\mathrm{H}}\right.$ $\left.1.69 ; \delta_{\mathrm{C}} 19.9\right)$ and $\left(\delta_{\mathrm{H}} 2.23 ; \delta_{\mathrm{C}} 20.9\right)$. The resonance signals in the ${ }^{1} \mathrm{H}$ NMR at $\delta_{\mathrm{H}} 7.12(\mathrm{~d}, J=6.8 \mathrm{~Hz}, 2 \mathrm{H}), 7.30$ (t, $J=6.8 \mathrm{~Hz}, 2 \mathrm{H})$, and $7.24(\mathrm{~m}, 1 \mathrm{H})$ disclosed that there was a monosubstituted phenyl moiety in the molecule, which was evidenced by the ${ }^{13} \mathrm{C}$ NMR signals at $\delta_{\mathrm{C}} 129.2(2 \mathrm{C})$, 129.0 (2C), 127.2 (1C), and 137.6 (1C). In addition, three pairs of double bands were also determined based on the signals at $\left(\delta_{\mathrm{H}} 5.80, \mathrm{dd}, J=16.0 \mathrm{~Hz}, J=10.0 \mathrm{~Hz} ; \delta_{\mathrm{C}} 132.1\right)$, $\left(\delta_{\mathrm{H}} 5.08\right.$, ddd, $J=15.2 \mathrm{~Hz}, J=10.8 \mathrm{~Hz}, J=4.4 \mathrm{~Hz} ; \delta_{\mathrm{C}}$ $132.4),\left(\delta_{\mathrm{H}} 4.75\right.$, ddd, $J=16.0 \mathrm{~Hz}, J=7.6 \mathrm{~Hz}, J=2.4 \mathrm{~Hz}$; $\left.\delta_{\mathrm{C}} 124.5\right),\left(\delta_{\mathrm{H}} 6.04, \mathrm{ddd}, J=16.0 \mathrm{~Hz}, J=2.8 \mathrm{~Hz}\right.$, $\left.J=1.2 \mathrm{~Hz} ; \delta_{\mathrm{C}} 132.6\right),\left(\delta_{\mathrm{H}} 5.31, \mathrm{~s} ; \delta_{\mathrm{C}} 127.7\right)$, and $\left(\delta_{\mathrm{C}}\right.$ 138.1) in the ${ }^{1} \mathrm{H}$ and ${ }^{13} \mathrm{C}$ NMR data. In conjunction with the 1D and 2D NMR data, the remaining carbon signals were designated two methylenes, six methines, an oxygenated tertiary carbon, a $\mathrm{sp}^{3}$ quarternary carbon, and three carbonyl groups. Unambiguously, these evidences exhibited that compound $\mathbf{1}$ was a cytochalasin derivative $[4,27]$. The polyketide moiety of 1 was constructed on the basis of the ${ }^{1} \mathrm{H}-{ }^{1} \mathrm{H}$ COSY couplings of $\mathrm{H}-21 / \mathrm{H}-20 / \mathrm{H}-$ 19/H-18/H-23 and H-7/H-8/H-13/H-14/H-15/H-16/H-22 and $\mathrm{HMBC}$ cross-peaks from $\mathrm{H}_{3}-11$ to $\mathrm{C}-5$ and $\mathrm{C}-6$, from $\mathrm{H}_{3}-12$ to C-6 and C-7, from $\mathrm{H}-7$ to C-6 and C-8, from $\mathrm{H}-8$ to C-9, from $\mathrm{H}-21$ to $\mathrm{C}-1, \mathrm{C}-9$, and C-20, from $\mathrm{H}_{3}-22$ to $\mathrm{C}-15, \mathrm{C}-16$, and $\mathrm{C}-17$, from $\mathrm{H}-16$ to $\mathrm{C}-15$ and $\mathrm{C}-17$, from $\mathrm{H}_{3}-23$ to $\mathrm{C}-18$ and $\mathrm{C}-17$, and from $\mathrm{H}-18$ to $\mathrm{C}-17$ and $\mathrm{C}-16$ (Fig. 2). The moiety of phenylalanine was established by the ${ }^{1} \mathrm{H}-{ }^{1} \mathrm{H}$ COSY couplings of $\mathrm{H}-2^{\prime} / \mathrm{H}-3^{\prime} / \mathrm{H}-4^{\prime} / \mathrm{H}-5^{\prime} / \mathrm{H}-6^{\prime}$ and $\mathrm{HMBC}$ cross-peaks from $\mathrm{H}-10$ to $\mathrm{C}-1^{\prime}, \mathrm{C}-2^{\prime}, \mathrm{C}-3$, and C-4, from $\mathrm{H}-4$ to $\mathrm{C}-1$ and $\mathrm{C}-9$, and from $\mathrm{H}-21$ to $\mathrm{C}-4$ and C-9, from NH to C-1, C-3, and C-4, and from H-3 to C-1' (Fig. 2). Ultimately, the linkage between these two moieties was deduced from the ${ }^{1} \mathrm{H}-{ }^{1} \mathrm{H}$ COSY correlations of $\mathrm{H}-11 / \mathrm{H}-5 / \mathrm{H}-4 / \mathrm{H}-3 / \mathrm{H}-10$ and HMBC cross-peaks from NH to $\mathrm{C}-1$ and $\mathrm{C}-9$, from $\mathrm{H}-11$ to $\mathrm{C}-4$, and from $\mathrm{H}-4$ to $\mathrm{C}-5$ and $\mathrm{C}-6$, as depicted in Figs. 1 and 2. The chemical shift 


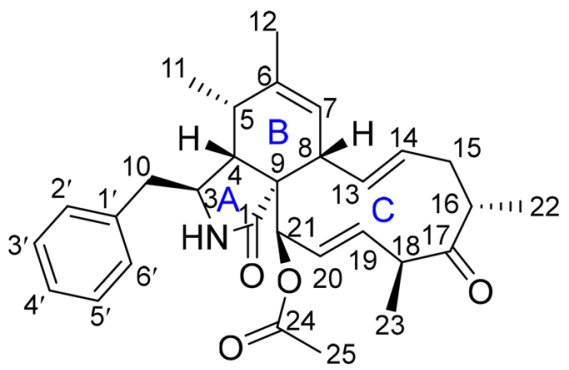

1<smiles>CC(=O)O/C=C/[C@]12C(=O)N[C@H](Cc3ccccc3)[C@H]1[C@@H](C)C(C)=C[C@H]2/C=C/C[C@@H](C)C(=O)C(C)(O)O</smiles>

4

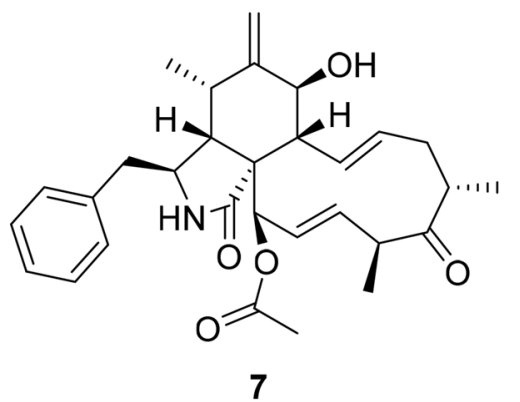

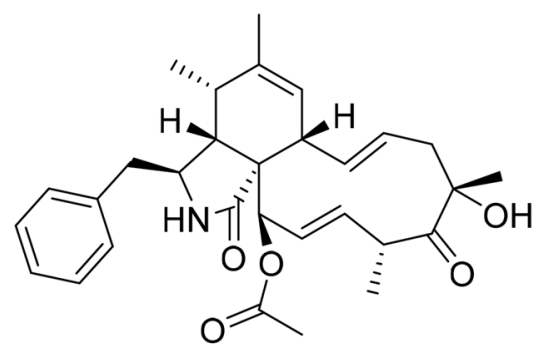

2<smiles>CC(=O)O/C=C\C(C)(O)C(=O)[C@@H](C)C/C=C\[C@]12C(=O)N[C@H](Cc3ccccc3)[C@H]1[C@@H](C)C(CO)=C[C@H]2C</smiles>

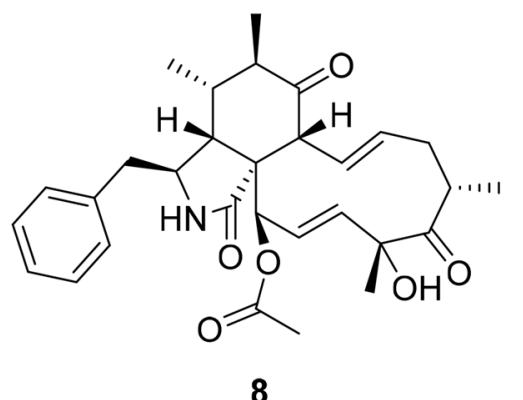

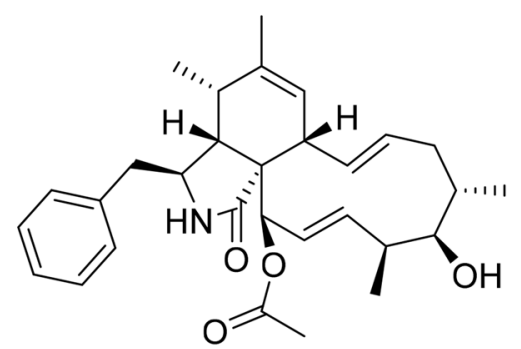

3

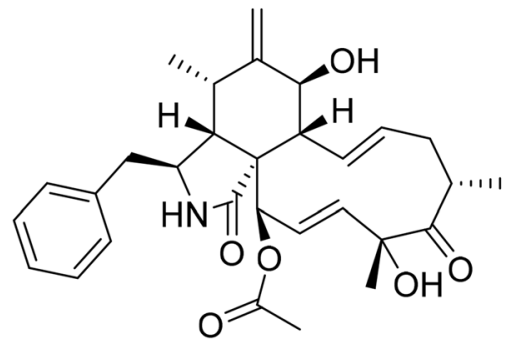

6

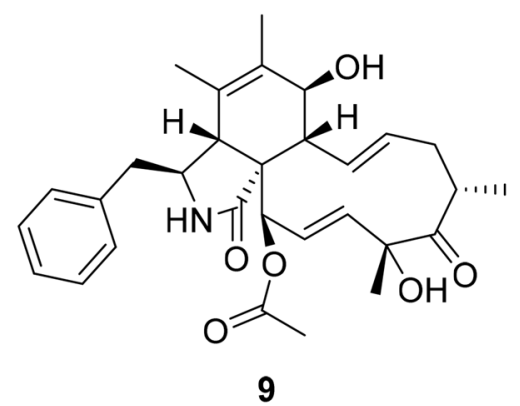

Fig. 1 Structures of compounds $\mathbf{1}-\mathbf{9}$

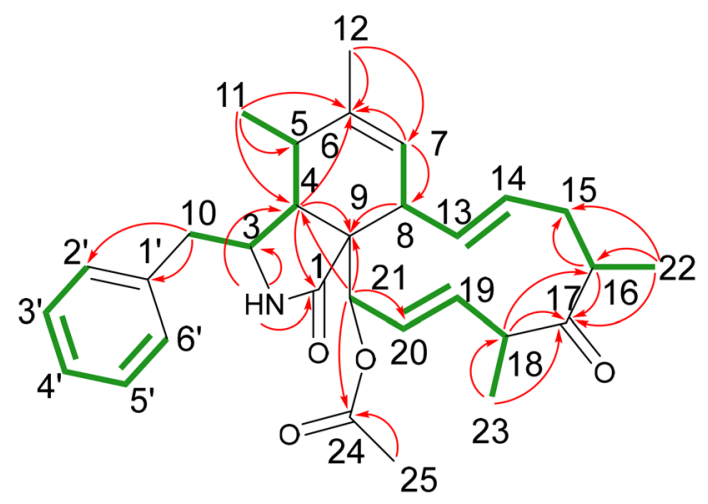

$-{ }^{1} \mathrm{H}-{ }^{1} \mathrm{H}$ COSY

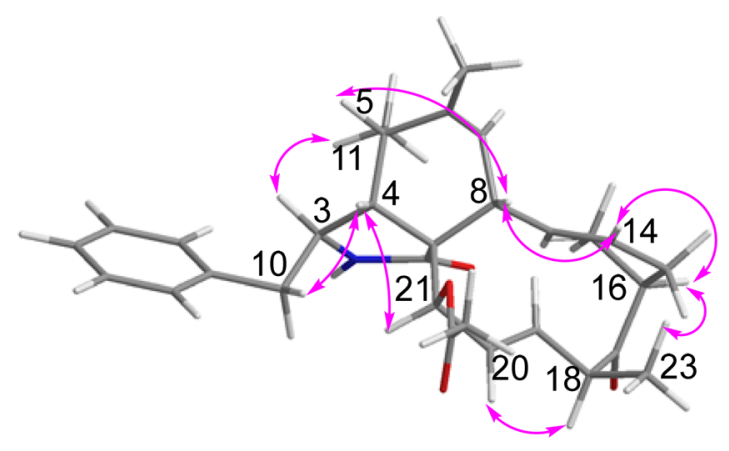

$\because$ NOESY

Fig. 2 Key ${ }^{1} \mathrm{H}-{ }^{1} \mathrm{H}$ COSY, HMBC, and NOESY correlations of compound $\mathbf{1}$ 
of C-21 $\left(\delta_{\mathrm{H}} 5.53, \mathrm{~s} ; \delta_{\mathrm{C}} 77.2\right)$ and the HMBC cross-peaks of $\mathrm{H}-21$ to $\mathrm{C}-24$ and $\mathrm{H}_{3}-25$ to $\mathrm{C}-24$ revealed that the acetyl group was connected to C-21. Herein, the planar structure of compound 1 was determined as depicted in Fig. 1.

The relative configuration of compound $\mathbf{1}$ was determined by the NOESY experiment. The NOESY correlations of $\mathrm{H}-5 / \mathrm{H}-8, \mathrm{H}_{3}-11 / \mathrm{H}-3, \mathrm{H}-4 / \mathrm{H}-10$ a suggested that $\mathrm{H}-8$, $\mathrm{H}-4$, and $\mathrm{H}_{2}-10$ were cofical and assigned as $\beta$ orientation. Accordingly, $\mathrm{H}_{3}-11$ and $\mathrm{H}-3$ were $\alpha$ oriented. The correlations of $\mathrm{H}-16$ with $\mathrm{H}_{3}-23$, H-8 with $\mathrm{H}-14, \mathrm{H}-14$ with $\mathrm{H}-16$, and $\mathrm{H}-4$ with $\mathrm{H}-21$ in the NOESY spectrum revealed that $\mathrm{H}_{3}-22$ and $\mathrm{H}-21$ were $\alpha$ oriented, the configuration of C-9 was $S^{*}, \mathrm{H}_{3}-23$ was $\beta$ oriented, and the $\Delta^{13}$ double bond was $E$-configuration $[27,28]$. The $\Delta^{19}$ double bond was $E$ - configuration on the basis of the NOESY correlation of H-18 and $\mathrm{H}-20$. Subsequently, these data confirmed the relative configuration of $\mathbf{1}$, which offered two possible stereo-structure candidates assembled as $1 \mathbf{a}(3 S, 4 R, 5 S, 8 S, 9 S, 16 S, 18 S$, $21 R)$ and $\mathbf{1 b}(3 R, 4 S, 5 R, 8 R, 9 R, 16 R, 18 R, 21 S)$. The ECD spectra of both $\mathbf{1 a}$ and $\mathbf{1 b}$ were calculated. The ECD values for 1a showed negative ( $212 \mathrm{~nm}$ and $308 \mathrm{~nm}$ ) and positive $(245 \mathrm{~nm})$ cotton effects, the shape of which matched with that of the experimental curve (Fig. 3). Thus, the absolute configuration of compound $\mathbf{1}$ was determined as
$3 S, 4 R, 5 S, 8 S, 9 S, 16 S, 18 S, 21 R$, and the name of xylariasin A was proposed for $\mathbf{1}$.

Compound 2, a coreless oil, which was evidenced to possess a molecular formula of $\mathrm{C}_{30} \mathrm{H}_{37} \mathrm{NO}_{5}$ from its (+)-HRESIMS ion at $m / z, 492.2741\left([\mathrm{M}+\mathrm{H}]^{+}\right.$, calcd for $\mathrm{C}_{30} \mathrm{H}_{38} \mathrm{NO}_{5}$ 492.2744) and ${ }^{13} \mathrm{C}$ NMR data, indicating the presence of 13 IOHDs. Absorption bands at 1740 and $1692 \mathrm{~cm}^{-1}$ (carbonyl groups), and 3456 and $3302 \mathrm{~cm}^{-1}$ (amino/hydroxyl groups) in the IR spectra were designated. The characteristic resonances included signals for a monosubstituted phenyl moiety at $\delta_{\mathrm{H}} 7.12(\mathrm{~d}, J=6.8 \mathrm{~Hz}, 2 \mathrm{H}), 7.30$ $(\mathrm{t}, J=6.8 \mathrm{~Hz}, 2 \mathrm{H})$, and $7.24(\mathrm{~m})$ and five methyl groups at $\delta_{\mathrm{H}}$ 1.15 (d, $J=7.2 \mathrm{~Hz}), 1.19$ (d, $J=6.8 \mathrm{~Hz}), 1.71(\mathrm{~s}), 1.42(\mathrm{~s})$, and $2.21(\mathrm{~s})$, and olefinic and oxygenated protons at $\delta_{\mathrm{H}} 5.25$ (s), $6.18(\mathrm{~s}), 4.94(\mathrm{~m}), 4.98(\mathrm{~m}), 6.21(\mathrm{~s}), 5.49(\mathrm{~s})$, and 6.05 (s) in the ${ }^{1} \mathrm{H}$ NMR spectrum. These data are reminiscent of compound $\mathbf{1}$, suggesting that compound $\mathbf{2}$ was a similar cytochalasin derivative. The main difference between these two compounds in the ${ }^{1} \mathrm{H}$ NMR spectra was a methyl doublet in $\mathbf{1}$ became a methyl singlet in $\mathbf{2}$. Accordingly, the most obvious difference in their ${ }^{13} \mathrm{C}$ NMR spectra was the absence of a methine carbon in $\mathbf{1}$ and the presence of an oxygenated tertiary carbon at $\delta_{\mathrm{C}} 81.9$ in $\mathbf{2}$. These data supported a hypothesis that there was a hydroxyl group connected to

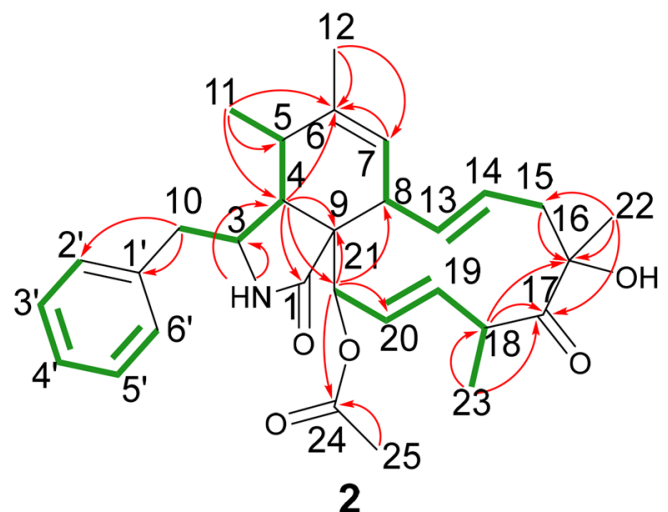

2

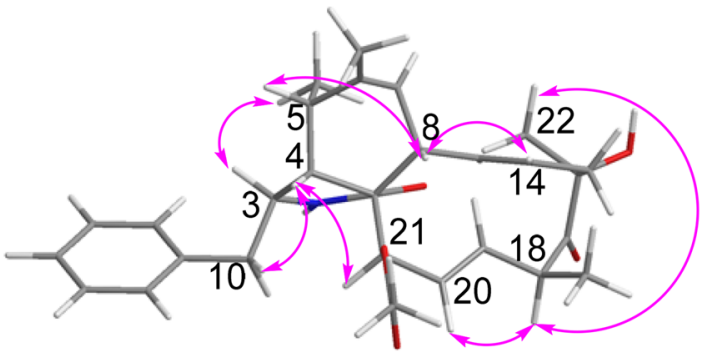

2
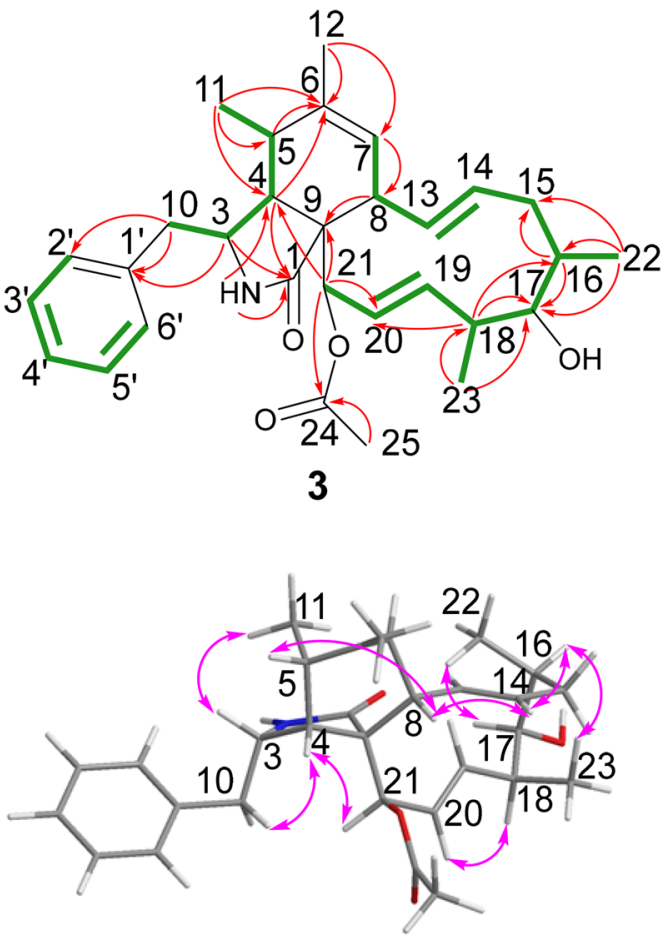

3

$-{ }^{1} \mathrm{H}-{ }^{1} \mathrm{H} \cos Y$

\section{HMBC (from $\mathrm{H}$ to $\mathrm{C}$ )}

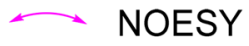

Fig. 3 Key ${ }^{1} \mathrm{H}-{ }^{1} \mathrm{H}$ COSY, HMBC, and NOESY correlations of compounds $\mathbf{2}$ and $\mathbf{3}$ 
C-16, which was confirmed by the HMBC cross-peaks from $\mathrm{H}-15$ to $\mathrm{C}-16$, from $\mathrm{H}_{3}-22$ to $\mathrm{C}-15, \mathrm{C}-16$, and $\mathrm{C}-17$, and from $\mathrm{H}-18$ to $\mathrm{C}-16$ and C-17. Thus, the planar structure of compound 2 was demonstrated as Fig. 4. The NOESY correlations of $\mathrm{H}-5 / \mathrm{H}-8, \mathrm{H}-3 / \mathrm{H}_{3}-11, \mathrm{H}-4 / \mathrm{H}-10$, and $\mathrm{H}-4 / \mathrm{H}-21$ revealed these protons possessed the same relative configurations with those of compound $\mathbf{1}$, which was demonstrated as part A in Fig. 5. The NOESY correlations of $\mathrm{H}-8 / \mathrm{H}-14$ and $\mathrm{H}-20 / \mathrm{H}-18$ revealed the $\Delta^{13}$ and $\Delta^{19}$ double bonds were E-configuration. The correlation between $\mathrm{H}_{3}-22$ and $\mathrm{H}-18$ in the NOESY spectrum revealed that $\mathrm{H}_{3}-22$ and $\mathrm{H}_{3}-23$ were located on the opposite side, described as part B in Fig. 5. However, $\mathrm{H}-16$ in 1 was replaced by a hydroxyl group in compound 2 , resulting in the absence of NOESY resonance signal of $\mathrm{H}-14 / \mathrm{H}-16$. The relative configurations of part A and part B cannot be coordinated based on the NOESY correlations, which gave two possibilities depicted as $\mathbf{2 a}$ and $\mathbf{2 b}$ in Fig. 5. Accordingly, four possible enantiomers $\mathbf{2 a - 2 d}$ (Fig. 5) were inferred to comprise the absolute configuration of 2.

The ECD spectra of $\mathbf{2 a}-\mathbf{2 d}$ were calculated through the density functional theory (DFT) optimization at the level of b3lyp/6-31 $\mathrm{g}(\mathrm{d}, \mathrm{p})$. The calculated ECD values of $(3 S, 4 R, 5 S, 8 S, 9 S, 16 S, 18 R, 21 R)-\mathbf{2}(\mathbf{2 b})$ exhibited good agreement with the experimental ECD values of 2 (Fig. 6), indicating 2 was $3 S, 4 R, 5 S, 8 S, 9 S, 16 S, 18 R, 21 R$. Accordingly, the calculated optical rotation for $\mathbf{2 b}$ was +9.55 , which was closer to the experimental data of $\mathbf{2}\left([\alpha]_{\mathrm{D}}^{19}=+13.559\right)$, supporting the absolute configuration of $\mathbf{2}$. Compound $\mathbf{2}$ was determined as depicted in Fig. 1 and defined as xylariasin B. The hydroxyl substituent at C-16 in cytochalasins was rare, and compound 2 was the first example, which indicated that there may be an oxidase responsible for hydroxylation of $\mathrm{C}-16$ in the biosynthesis pathway.

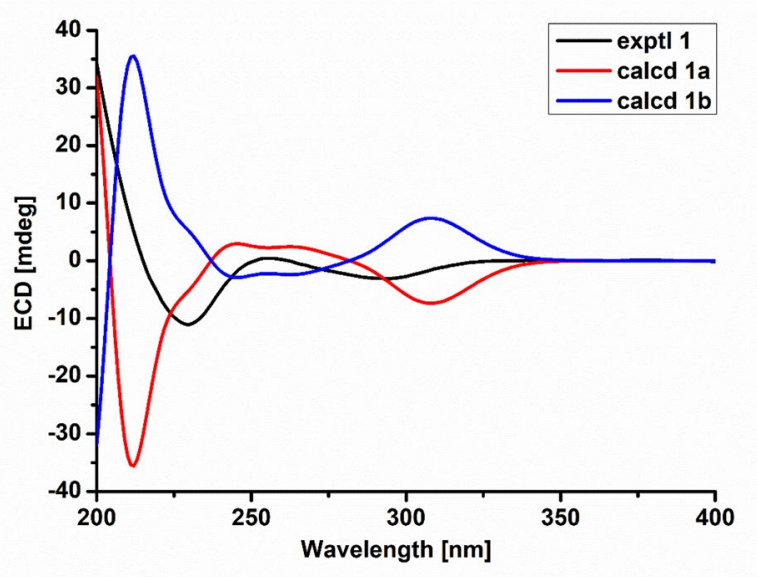

Fig. 4 ECD spectra of compound 1 (solvent: $\mathrm{CH}_{3} \mathrm{OH}$ )
Compound 3, a white powder, had a molecular formula of $\mathrm{C}_{30} \mathrm{H}_{39} \mathrm{NO}_{4}$, requiring $12 \mathrm{IOHDs}$, which was established by the ${ }^{13} \mathrm{C}$ NMR data and a sodium adduct ion peak at $\mathrm{m} / \mathrm{z}$ $500.2768\left([\mathrm{M}+\mathrm{Na}]^{+}\right.$, calcd 500.2771) in the HRESIMS spectrum. Inspection of the ${ }^{1} \mathrm{H}$ NMR spectrum with that of compound 1 suggested that they were analogues. The major difference was that there was an additional oxygenated methine proton at $\delta_{\mathrm{H}} 3.79$ in compound 3. Correspondingly, an oxygenated methine carbon replacing the carbonyl group was observed in the ${ }^{13} \mathrm{C}$ NMR spectrum of compound 3 . These data gave a deduction that the carbonyl group at $\mathrm{C}-17$ was changed to a hydroxyl group, in agreement with the fact that compound $\mathbf{3}$ possessed a less IOHD than compound 1. This assumption was subsequently supported by the key ${ }^{1} \mathrm{H}-{ }^{1} \mathrm{H}$ COSY correlations and the key HMBC correlations as depicted in Fig. 3. The NOESY correlation of $\mathrm{H}-17$ with $\mathrm{H}_{3}$-22 suggested that $\mathrm{H}-17$ was $\alpha$-oriented, in conjunction with the same NOESY correlations of compound 3 as those of compound 1, which gave two possibilities for the absolute configuration of compound $\mathbf{3}$, assigned as $\mathbf{3 a}$ $(3 S, 4 R, 5 S, 8 S, 9 S, 16 S, 17 R, 18 S, 21 R)$ and $\mathbf{3 b}(3 R, 4 S, 5 R, 8 R$, $9 R, 16 R, 17 R, 18 R, 21 S)$. The ECD curve of $\mathbf{3 a}$ was consistent with that of experimental curve (Fig. 7), evidencing the absolute configuration of $\mathbf{3}$ was $3 S, 4 R, 5 S, 8 S, 9 S, 16 S, 17 R$, $18 S, 21 R$. Further experimental specific rotation for compound 3 was -20.883 , approximating that of compound 1 $\left([\alpha]_{\mathrm{D}}^{19}=-18.853\right)$, which unambiguously certified the absolute configuration of $\mathbf{3}$. Thus, the structure of compound $\mathbf{3}$ was demonstrated in Fig. 1 and named xylariasin C.

By comparison with the published ${ }^{1} \mathrm{H}$ and ${ }^{13} \mathrm{C}$ NMR data, the six known cytochalasins were identified as zygosporin $\mathrm{G}$ (4) [29],12-hydroxyl zygosporin G (5) [30], cytochalasin D (6) [30, 31], zygosporin E (7) [30], compound 10 (8) [32], and cytochalasin C (9) [33].

Expect xylarasins B (2) and C (3), the cytotoxicity, LAG3/MHC II inhibition activity, and LAG3/FGL1 inhibition activity of all isolates were tested.

\subsection{Cytotoxic Activity}

Cytochalasin D (6) and cytochalasin C (9) exhibited strong cytotoxic activity against AGS cells. At a concentration of $5 \mu \mathrm{M}$, cytochalasin D (6) and cytochalasin C (9) possessed inhibition rates of $94 \%$ and $64 \%$, respectively.

\subsection{LAG3/MHC II Binding Inhibition Activity}

To explore anticancer immunosuppression activity of cytochalsins from Xylaria sp. CFL5, the effects of all isolates except xylariasins B (2) and C (3) against the binding between LAG3 and MHC II were investigated. As shown in Table 3 and Fig. 8, cytochalasin D (6) regrettably did not reveal obvious inhibition effects on the interaction between 

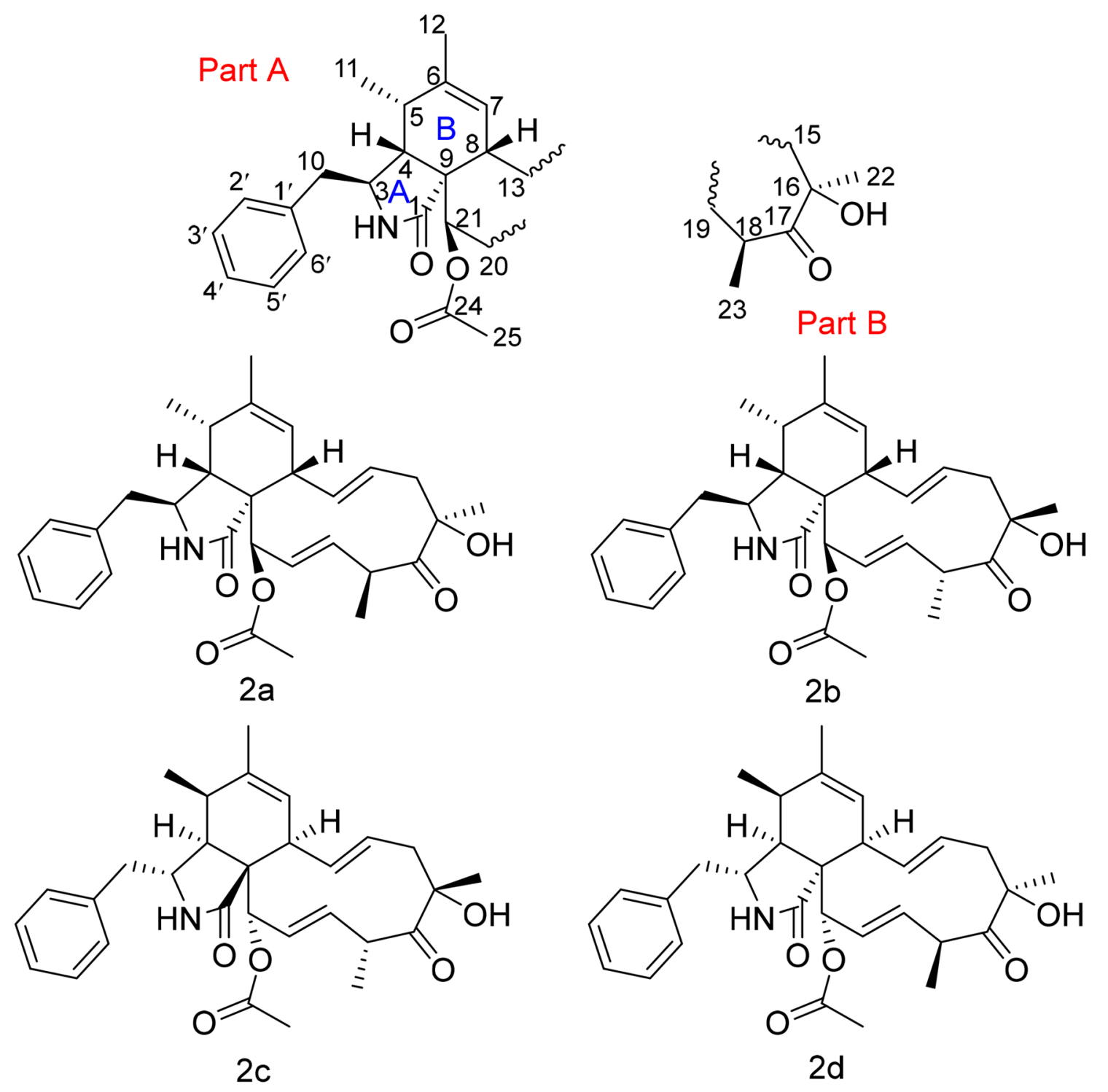

Fig. 5 The probable absolute configuration for compound $\mathbf{2}$

these two proteins, while zygosporin $\mathrm{G}$ (4) possessed an inhibition rate of $55.72 \%$ at the concentration of $50 \mu \mathrm{M}$. It was found that all the other tested compounds $(\mathbf{1}, \mathbf{5}, \mathbf{7 - 9})$ inhibited the binding of LAG3 protein and MHC II protein, exhibiting inhibition rates approximately $80 \%$. Compounds $1,5,7,8$ possessed $\mathrm{IC}_{50}$ values ranging from 2.37 to $4.74 \mu \mathrm{M}$, as demonstrated in Table 4 .

\subsection{LAG3/FGL1 Binding Inhibition Activity}

LAG3/FGL1 was a novel immunosuppression pathway independent of LAG3/MHC II. The inhibitors influencing the binding of LAG3 and FGL1 could also prevent tumor immune escape, which could make the tumor cells recognized and killed by $\mathrm{T}$ cells. Exploiting the inhibitors acting on the LAG3/FGL1 pathway could provide a possibility to the cancer immunotherapy. The inhibition activity of compounds 1, 4-9 against the interaction of LAG3/FGL1 were evaluated in vitro. The result was summarized in Fig. 8 and Tables 3 and 4 . At the concentration of $50 \mu \mathrm{M}$, compounds 4 and 9 exhibited moderate inhibition activity on the LAG3/ FGL1, with inhibition rates of $24.90 \%$ and $58.36 \%$, respectively. Compounds $\mathbf{1}, \mathbf{5}, \mathbf{7}$, and $\mathbf{8}$ possessed inhibition rates ranging from $79.11 \%$ to $92.70 \%$ at the same concentration. The $\mathrm{IC}_{50}$ values of compounds $1,7,8$ against the binding between LAG3 and FGL1 were 11.78, 4.39, and $7.45 \mu \mathrm{M}$, respectively.

In summary, nine cytochalasins including three undescribed ones (1-3) were isolated from Xylaria sp. CFL5, an endophytic fungus of Cephalotaxus fortunei. Interestingly, 

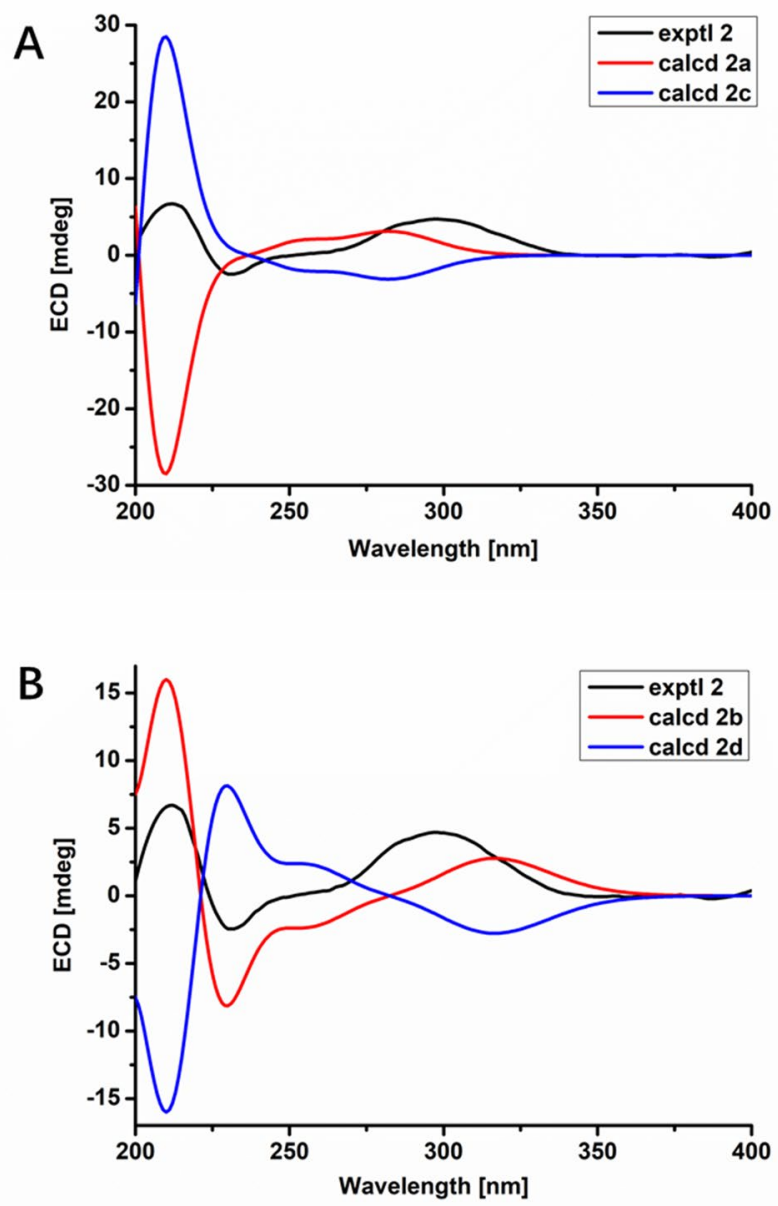

Fig. 6 ECD spectra of compound 2 (solvent: $\mathrm{CH}_{3} \mathrm{OH}$ )

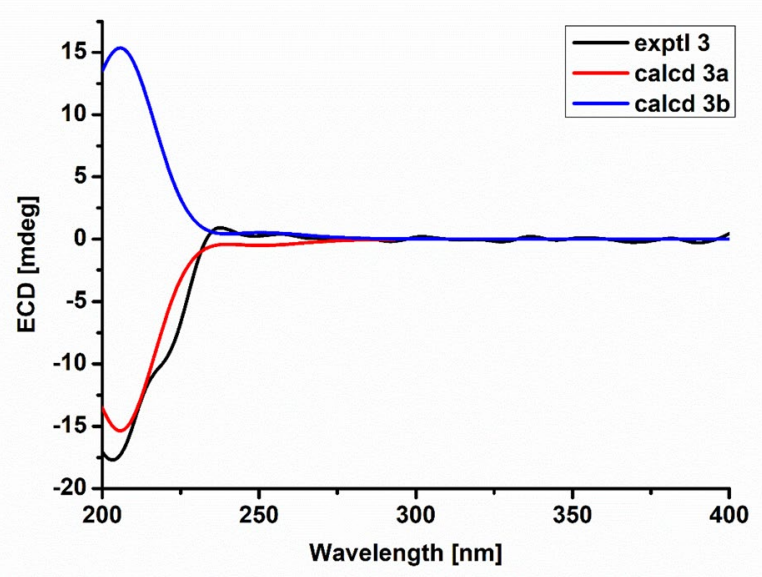

Fig. 7 ECD spectra of compound 3 (solvent: $\mathrm{CH}_{3} \mathrm{OH}$ )

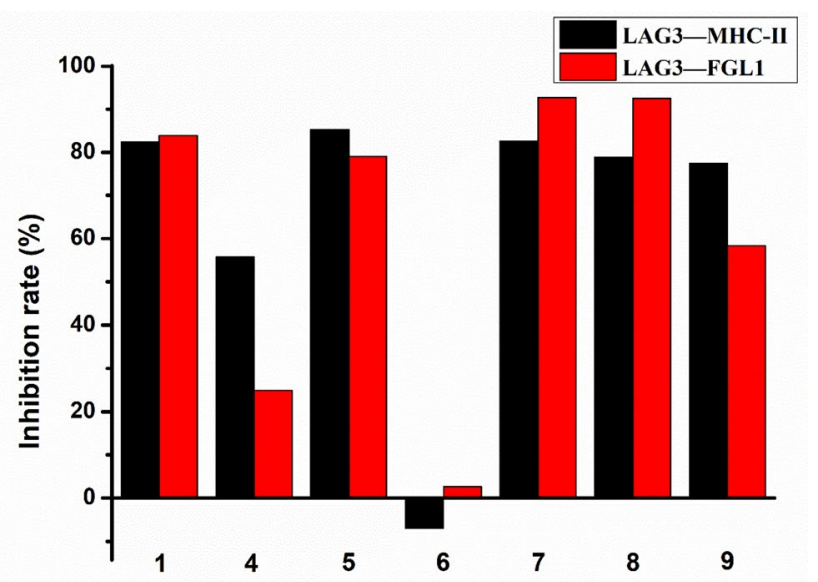

Fig. 8 The inhibition rates of tested compounds $(\mathbf{1}, \mathbf{4 - 9})$ against LAG3/MHC II and LAG3/FGL1 at a concentration of $50 \mu \mathrm{M}$

all tested isolates possessed biological activities, including cytotoxicity, LAG3/FGL1 binding inhibition activity, and LAG3/FGL1 binding inhibition activity. Cytochalasin D (6) and cytochalasin C (9) possessed cytotoxicity against AGS cells at $5 \mu \mathrm{M}$, with inhibition rates of $94 \%$ and $64 \%$, respectively. Except cytochalasin D (6), all tested compounds simultaneously showed inhibition effects on the interaction of LAG3 and MHC II, or LAG3 and FGL1 (Fig. 8). Compound 1, 5, 7, and $\mathbf{8}$ inhibited LAG3/MHC II with $\mathrm{IC}_{50}$ values ranging from 2.37 to $4.74 \mu \mathrm{M}$. Meanwhile, the $\mathrm{IC}_{50}$ values of compounds $\mathbf{1}, \mathbf{7}$, and $\mathbf{8}$ against LAG3/FGL1 were $11.78,4.39$, and $7.45 \mu \mathrm{M}$, respectively. Drugs acting on either LAG3/MHC II or LAG3/FGL1 pathway can play a part in preventing tumor immune escape. However, there were few small molecule inhibitors acting on LAG3/MHC II or LAG3/FGL1, and drugs targeting LAG3 are basically antibodies. Our research results supplemented the gap of small inhibitors on these two pathways, and it was the first report that cytochalasin derivatives can break the interactions of both LAG3/MHC II and LAG3/FGL1. These data provided cytochalasin derivatives with more possibilities of biological activities, highlighting the application potential in cancer immunotherapy.

\section{Experimental}

\subsection{General Experimental Procedures}

The optical rotations were measured using a PerkinElmer model 341 polarimeter. A Bruker Tensor spectrometer was used for the measurement of the IR spectra. A Shimadzu UV-260 spectrophotometer was used to measure the UV spectra. ${ }^{1} \mathrm{H},{ }^{13} \mathrm{C}$, and $2 \mathrm{D}$ NMR spectra were recorded on a Bruker AVANCE III-400, a Bruker AVANCE NEO 600, 
or a Varian Mercury-600BB spectrometer. The HRESIMS data were acquired utilizing a Bruker Daltonics APEX II spectrometer. The ECD curves were obtained on an Olis DSM-1000 spectrometer. The compounds were purified by a macroporous resin HP-20 and a semipreparative HPLC with a reversed-phase $\mathrm{C}_{18}(150 \times 10 \mathrm{~mm}, 10 \mu \mathrm{m})$ column. Silica gel (200-300 mesh) for column chromatography and Silica gel GF254 (10-40 $\mathrm{mm})$ for TLC were purchased from the Qingdao Marine Chemical Factory, Qingdao, China.

\subsection{Fungal Material}

The fungus was obtained from the leaves of Cephalotaxus fortunei Hook. The plant sample was collected from Feng County, Shaanxi Province, China in August, 2017, which was identified by the professor Huyuan Feng (School of Life Science, Lanzhou University). On the basis of the ITS sequence analysis, the fungus was identified as Xylaria sp. (Genbank: KU645984.1). The fungus was inoculated on a PDA plate to obtain mycelium. Then its mycelium was picked into an Erlenmeyer flasks $(100 \mathrm{~mL})$ with $50 \mathrm{~mL}$ of YMG medium, cultured at $28^{\circ} \mathrm{C}, 140 \mathrm{rpm}$ for 5 days. $2 \mathrm{~mL}$ of mediums were transferred into three Erlenmeyer flasks $(500 \mathrm{~mL})$ with $200 \mathrm{~mL}$ of YMG medium. After cultivation at the same condition for 7 days, the seed culture was given. Sequently, $10 \mathrm{~mL}$ of seed culture was carried out in 50 rice mediums ( $80 \mathrm{~g}$ rice, $4 \mathrm{~g}$ sucrose, $120 \mathrm{~mL}$ distilled water) and incubated at $28^{\circ} \mathrm{C}$ for 20 days.

\subsection{Extraction, Isolation, and Purification Process}

The solid mediums were extracted with EtOAc for three times. After removing the solvent under reduced pressure, a crude extract $(53.9 \mathrm{~g})$ was given. The crude extract was submitted to a macroporous resin HP-20 chromatographic column and eluted with a gradient elution $(30 \%, 50 \%, 80 \%$, 95\% EtOH) to yield four fractions (Fr. 1-4). Fr. 3 (17.2 g) was purified using a silica gel column with a gradient elution (petroleum ether-ethyl acetate, 10:1 to 1:2) as eluent. Seven fractions (Fr. 3A-3G) were given after combination and concentration with TLC analysis. Fr. 3B (400 mg) was purification with a reversed-phase semipreparative HPLC $\left(\mathrm{CH}_{3} \mathrm{CN} / \mathrm{H}_{2} \mathrm{O}, 7 / 3\right.$, v/v) to give compounds $1(4.7 \mathrm{mg}$, $\left.\mathrm{t}_{\mathrm{R}}=30 \mathrm{~min}\right)$ and $2\left(2.6 \mathrm{mg}, \mathrm{t}_{\mathrm{R}}=16 \mathrm{~min}\right)$. Compound 4 $\left(20 \mathrm{mg}, \mathrm{t}_{\mathrm{R}}=38 \mathrm{~min}\right)$ was obtained from Fr. $3 \mathrm{C}(560 \mathrm{mg})$ with a reversed-phase semipreparative HPLC $\left(60 \% \mathrm{CH}_{3} \mathrm{CN}\right)$. The purification of Fr. 3D (1.4 g) with a reversed-phase semipreparative HPLC $\left(85 \% \mathrm{CH}_{3} \mathrm{OH}\right)$ yielded compound $3\left(2.2 \mathrm{mg}, \mathrm{t}_{\mathrm{R}}=20 \mathrm{~min}\right)$. Fr. $3 \mathrm{E}(3.7 \mathrm{~g})$ was isolated with a reversed-phase semipreparative HPLC $\left(\mathrm{CH}_{3} \mathrm{CN} / \mathrm{H}_{2} \mathrm{O}\right.$, $115 / 85, \mathrm{v} / \mathrm{v})$ to obtain compounds $8\left(3.2 \mathrm{mg}, \mathrm{t}_{\mathrm{R}}=50 \mathrm{~min}\right)$ and $9\left(2.8 \mathrm{mg}, \mathrm{t}_{\mathrm{R}}=60 \mathrm{~min}\right)$. Using $\left(\mathrm{MeCN} / \mathrm{H}_{2} \mathrm{O}=101: 99\right.$, $\mathrm{v} / \mathrm{v})$ as the eluent, compounds $5\left(80.2 \mathrm{mg}, \mathrm{t}_{\mathrm{R}}=18 \mathrm{~min}\right), \mathbf{6}$ $\left(7.7 \mathrm{mg}, \mathrm{t}_{\mathrm{R}}=22 \mathrm{~min}\right)$, and $7\left(2.4 \mathrm{mg}, \mathrm{t}_{\mathrm{R}}=32 \mathrm{~min}\right)$ were purified from Fr. 3F ( $4.7 \mathrm{~g})$ by a reversed-phase semipreparative HPLC.

Xylariasin A (1): white powder; $[\alpha]_{\mathrm{D}}^{19}=-18.853(\mathrm{MeOH}$, $c$ 1.273); IR (KBr) $\nu_{\max } 3324,2963,2926,1743,1703,1604$, 1456, 1227, 1098, 1037, 737, $702 \mathrm{~cm}^{-1}$; ECD (MeOH) $\lambda_{\max }(\Delta \varepsilon), 229(-10.57), 256(+0.43), 294(-3.10) \mathrm{nm}$; HRESIMS $[\mathrm{M}+\mathrm{H}]^{+} m / z 476.2793$ (calcd for $\mathrm{C}_{30} \mathrm{H}_{38} \mathrm{NO}_{4}$ 476.2795); ${ }^{1} \mathrm{H}$ and ${ }^{13} \mathrm{C}$ NMR data, found in Tables 1 and 2.

Xylariasin B (2): colorless oil; $[\alpha]_{\mathrm{D}}^{19}=+13.559(\mathrm{MeOH}, c$ 0.885); IR (KBr) $\nu_{\max } 3456,3302,2969,2933,1740,1692$, $1454,1373,1229,738,702 \mathrm{~cm}^{-1}$; ECD $(\mathrm{MeOH}) \lambda_{\max }(\Delta \varepsilon)$, $212(+6.70), 231(-2.44), 243(-0.50), 266(+0.70), 298$ $(+4.70) \mathrm{nm}$; HRESIMS $[\mathrm{M}+\mathrm{H}]^{+} \mathrm{m} / z 492.2741$ (calcd for $\mathrm{C}_{30} \mathrm{H}_{38} \mathrm{NO}_{5}$ 492.2744); ${ }^{1} \mathrm{H}$ and ${ }^{13} \mathrm{C}$ NMR data, found in Tables 1 and 2.

Xylariasin C (3): white powder; $[\alpha]_{\mathrm{D}}^{19}=-20.883(\mathrm{MeOH}$, c 0.336); IR (KBr) $\nu_{\max } 3369,2925,1773,1719,1686,1262$, $1232,1107,1074,1027,740,702 \mathrm{~cm}^{-1}$; ECD $(\mathrm{MeOH}) \lambda_{\max }$ $(\Delta \varepsilon), 203(-17.70), 222(-8.82) \mathrm{nm}$; HRESIMS $[\mathrm{M}+\mathrm{Na}]^{+}$ $\mathrm{m} / \mathrm{z} 500.2768$ (calcd for $\mathrm{C}_{30} \mathrm{H}_{39} \mathrm{NO}_{4} \mathrm{Na} 500.2771$ ); ${ }^{1} \mathrm{H}$ and ${ }^{13} \mathrm{C}$ NMR data, found in Tables 1 and 2.

\subsection{Cytotoxicity Assay}

With adriamycin as the positive control, compounds 1, 4-9 were assessed for cytotoxicity against AGS, U251, and MDA-MB-231 by the CCK8 assay (Tables 3 and 4).

\subsection{LAG3/MHC II Binding Assay}

Utilizing HTRF (Homogeneous Time-resolved Fluorescence) technology [34,35], the inhibition activity of tested compounds interfering in the interaction between MHC II and LAG3 proteins was evaluated. The activity was measured using LAG3/MHC II binding assay kit commercially available from Cisbio. The tested compounds were dissolved with DMSO, then diluted with the diluent provided in the kit to give the tested solutions. $2 \mu \mathrm{L}$ tested solutions, $4 \mu \mathrm{L}$ Tag1-LAG3 protein, and $4 \mu \mathrm{L}$ Tag2-MHC II protein were added in sterile 96-well dishes. After incubation for $15 \mathrm{~min}$ in room temperature, $5 \mu \mathrm{L}$ anti-Tag1- $\mathrm{Tb}^{3+}$ and $5 \mu \mathrm{L}$ anti-Tag2-XL665 (or $10 \mu \mathrm{L}$ of pre-mixed anti-tag detection reagents) were added into each well. The concentration of DMSO in each well was kept below $0.5 \%$ and the final volume in each well was $20 \mu \mathrm{L}$ in the moment. Then the 96-well dishes were kept incubating for $1 \mathrm{~h}$ to overnight at room temperature. Subsequently, remove the plate sealer and read specific emission signal at $665 \mathrm{~nm}$ on an HTRF compatible reader. The positive control was yielded by replacing tested solution with $2 \mu \mathrm{L}$ diluent. The negative control consisted of $4 \mu \mathrm{L}$ Tag2-MHC II protein, $5 \mu \mathrm{L}$ anti-Tag1-Tb ${ }^{3+}$ and $5 \mu \mathrm{L}$ anti-Tag2-XL665, as well as $6 \mu \mathrm{L}$ diluent. In blank control, 5 
Table $1{ }^{1} \mathrm{H}$ NMR Spectroscopic Data (in $\mathrm{CDCl}_{3}, J$ in $\mathrm{Hz}$ ) for Compounds 1, 2, and 3

\begin{tabular}{|c|c|c|c|}
\hline Position & $\mathbf{1}^{\mathrm{a}}$ & $2^{a}$ & $3^{\mathrm{b}}$ \\
\hline 3 & 3.16 , dd $(8.4,4.0)$ & $3.13, \mathrm{~m}$ & $3.17, \mathrm{~m}$ \\
\hline 4 & $2.13, \mathrm{t}(4.4)$ & $2.14, \mathrm{t}(4.0)$ & $2.16, \mathrm{t}(4.2)$ \\
\hline 5 & $2.42, \mathrm{br} \mathrm{s}$ & 2.41, br s & 2.45, br s \\
\hline 7 & $5.31, \mathrm{~s}$ & $5.25, \mathrm{~s}$ & 5.37, s \\
\hline 8 & $3.12, \mathrm{~m}$ & $3.08, \mathrm{~d}(8.8)$ & $3.18, \mathrm{~m}$ \\
\hline \multirow[t]{2}{*}{10} & a $2.87, \mathrm{dd}(13.6,4.4)$ & a $2.92, \mathrm{dd}(13.6,3.6)$ & a $2.89, \mathrm{dd}(13.8,4.2)$ \\
\hline & b 2.57, dd $(13.6,9.6)$ & b $2.53, \mathrm{dd}(13.6,10.0)$ & b 2.59 , dd $(13.2,9.6)$ \\
\hline 11 & $1.10, \mathrm{~d}(7.6)$ & $1.15, \mathrm{~d}(7.2)$ & $1.13, \mathrm{~d}(7.2)$ \\
\hline 12 & $1.69, \mathrm{~s}$ & $1.71, \mathrm{~s}$ & $1.71, \mathrm{~s}$ \\
\hline 13 & $5.80, \mathrm{dd}(16.0,10.0)$ & $6.18, \mathrm{~s}$ & $5.85, \mathrm{dd}(15.6,10.2)$ \\
\hline 14 & $5.08, \operatorname{ddd}(15.2,10.8,4.4)$ & $4.94, \mathrm{~m}$ & 5.09, ddd $(15.6,10.8,4.8)$ \\
\hline \multirow[t]{2}{*}{15} & a $2.29, \mathrm{~m}$ & a $2.69, \mathrm{~m}$ & a $1.92, \mathrm{dd}(12.6,4.8)$ \\
\hline & b $2.00, \mathrm{dt}(12.8,6.0)$ & b 2.61, m & b 1.87, t (12.0) \\
\hline 16 & 2.64, ddd $(9.6,6.8,2.4)$ & & $1.57, \mathrm{~m}$ \\
\hline 17 & & & $3.79, \mathrm{~s}$ \\
\hline 18 & $3.25, \mathrm{t}(7.2)$ & $3.72, \mathrm{~m}$ & $2.50, \mathrm{~m}$ \\
\hline 19 & 4.75 , ddd $(16.0,7.6,2.4)$ & $4.98, \mathrm{~m}$ & 4.86, ddd $(15.0,7.2,1.8)$ \\
\hline 20 & 6.04, ddd $(16.0,2.8,1.2)$ & $6.21, \mathrm{~s}$ & $6.00, \mathrm{~d}(16.2)$ \\
\hline 21 & $5.53, \mathrm{~s}$ & $5.49, \mathrm{~s}$ & $5.60, \mathrm{~s}$ \\
\hline 22 & $1.15, \mathrm{~d}(6.8)$ & $1.42, \mathrm{~s}$ & $0.99, \mathrm{~d}(7.2)$ \\
\hline 23 & $1.22, \mathrm{~d}(7.2)$ & $1.19, \mathrm{~d}(6.8)$ & $0.98, \mathrm{~d}(6.6)$ \\
\hline 25 & $2.23, \mathrm{~s}$ & $2.21, \mathrm{~s}$ & $2.23, \mathrm{~s}$ \\
\hline $2^{\prime} / 6^{\prime}$ & $7.12, \mathrm{~d}(6.8)$ & $7.12, \mathrm{~d}(6.8)$ & $7.14, \mathrm{~d}(7.8)$ \\
\hline $3^{\prime} / 5^{\prime}$ & $7.30, \mathrm{t}(6.8)$ & $7.31, \mathrm{t}(7.6)$ & $7.32, \mathrm{t}(7.2)$ \\
\hline $4^{\prime}$ & $7.24, \mathrm{~m}$ & 7.26, m & $7.25, \mathrm{~m}$ \\
\hline $\mathrm{NH}$ & $5.89, \mathrm{~s}$ & $6.05, \mathrm{~s}$ & $5.43, \mathrm{~s}$ \\
\hline
\end{tabular}

${ }^{\text {a Recorded in }} 400 \mathrm{MHz}, \mathrm{TMS}, \delta$ in ppm

${ }^{\mathrm{b}}$ Recorded in $600 \mathrm{MHz}$, TMS, $\delta$ in ppm $\mu \mathrm{L}$ anti-Tag $1-\mathrm{Tb}^{3+}, 10 \mu \mathrm{L}$ diluent, and $5 \mu \mathrm{L}$ detection buffer were existed.

Using the following fluorescence intensity $(\mathrm{F})$ measurements at $665 \mathrm{~nm}$, such as the signals of positive control $\left(\mathrm{F}_{\mathrm{p}}\right)$, blank control $\left(\mathrm{F}_{\mathrm{b}}\right)$, and experimental groups $\left(\mathrm{F}_{\mathrm{e}}\right)$, the inhibition rate was calculated at each of the compound concentration levels. The inhibitory activity of compound against the interaction of LAG3 with MHC II was evaluated based on the formula as follow: Inhibition rate $=\left(F_{p}-F_{e}\right) /$ $\left(\mathrm{F}_{\mathrm{p}}-\mathrm{F}_{\mathrm{b}}\right) \times 100 \% . \mathrm{IC}_{50}$ values were calculated by linear regression of a dose-dependent inhibition rate curve.

\subsection{LAG3/FGL1 Binding Assay}

The tested principles and methods were similar to those of LAG3/MHC II. Using LAG3/FGL1 binding assay kit from Cisbio, the inhibition activity of tested compounds on the binding between LAG3 and MHC II was evaluated. The ligand protein in this kit was Tag2-FGL1 protein, which was distinguished from Tag2-MHC II protein. Moreover, the compositions of tested groups, positive control, negative control, blank control were analogical with those of LAG3/ MHC II kit. The experimental operations and statistical analysis were also identical with above-mentioned LAG3/ MHC II kit. 
Table $2{ }^{13} \mathrm{C}$ NMR Spectroscopic Data (Recorded in $150 \mathrm{MHz}$, in $\mathrm{CDCl}_{3}$ ) for compounds $\mathbf{1}, \mathbf{2}$, and $\mathbf{3}$

\begin{tabular}{|c|c|c|c|}
\hline Position & 1 & 2 & 3 \\
\hline 1 & $175.3, \mathrm{C}$ & 176.1, C & 175.3, C \\
\hline 3 & $55.8, \mathrm{CH}$ & $56.0, \mathrm{CH}$ & $55.8, \mathrm{CH}$ \\
\hline 4 & $53.8, \mathrm{CH}$ & $53.5, \mathrm{CH}$ & $54.5, \mathrm{CH}$ \\
\hline 5 & $35.3, \mathrm{CH}$ & $35.2, \mathrm{CH}$ & $35.4, \mathrm{CH}$ \\
\hline 6 & 138.1, C & 138.5, C & 137.8, C \\
\hline 7 & 127.7, $\mathrm{CH}$ & 127.2, $\mathrm{CH}$ & $128.1, \mathrm{CH}$ \\
\hline 8 & $43.0, \mathrm{CH}$ & $42.1, \mathrm{CH}$ & $43.3, \mathrm{CH}$ \\
\hline 9 & $57.4, \mathrm{C}$ & 55.6, C & $57.0, \mathrm{C}$ \\
\hline 10 & $45.9, \mathrm{CH}_{2}$ & $45.8, \mathrm{CH}_{2}$ & $46.1, \mathrm{CH}_{2}$ \\
\hline 11 & $14.2, \mathrm{CH}_{3}$ & $14.7, \mathrm{CH}_{3}$ & $14.1, \mathrm{CH}_{3}$ \\
\hline 12 & $19.9, \mathrm{CH}_{3}$ & $20.1, \mathrm{CH}_{3}$ & $20.0, \mathrm{CH}_{3}$ \\
\hline 13 & $132.1, \mathrm{CH}$ & $135.3, \mathrm{CH}$ & $130.1, \mathrm{CH}$ \\
\hline 14 & $132.4, \mathrm{CH}$ & $129.0, \mathrm{CH}$ & $134.0, \mathrm{CH}$ \\
\hline 15 & 37.6, $\mathrm{CH}_{2}$ & $42.7, \mathrm{CH}_{2}$ & $40.8, \mathrm{CH}_{2}$ \\
\hline 16 & $44.0, \mathrm{CH}$ & $81.9, \mathrm{C}$ & $32.8, \mathrm{CH}$ \\
\hline 17 & $211.8, \mathrm{C}$ & 216.3, C & $78.5, \mathrm{CH}$ \\
\hline 18 & $50.2, \mathrm{CH}$ & $46.3, \mathrm{CH}$ & $43.0, \mathrm{CH}$ \\
\hline 19 & $124.5, \mathrm{CH}$ & 127.2, CH & $131.2, \mathrm{CH}$ \\
\hline 20 & $132.6, \mathrm{CH}$ & $131.4, \mathrm{CH}$ & $129.6, \mathrm{CH}$ \\
\hline 21 & 77.2, $\mathrm{CH}$ & 76.7, CH & $77.5, \mathrm{CH}$ \\
\hline 22 & $19.1, \mathrm{CH}_{3}$ & $25.5, \mathrm{CH}_{3}$ & $17.1, \mathrm{CH}_{3}$ \\
\hline 23 & $16.3, \mathrm{CH}_{3}$ & $18.7, \mathrm{CH}_{3}$ & $12.3, \mathrm{CH}_{3}$ \\
\hline 24 & $170.0, \mathrm{C}$ & 170.0, C & $170.2, \mathrm{C}$ \\
\hline 25 & $20.9, \mathrm{CH}_{3}$ & $20.1, \mathrm{CH}_{3}$ & $21.0, \mathrm{CH}_{3}$ \\
\hline $1^{\prime}$ & 137.6, C & $137.5, \mathrm{C}$ & $137.9, \mathrm{C}$ \\
\hline $2^{\prime} / 6^{\prime}$ & $129.2, \mathrm{CH}$ & $129.0, \mathrm{CH}$ & $129.1, \mathrm{CH}$ \\
\hline $3^{\prime} / 5^{\prime}$ & $129.0, \mathrm{CH}$ & $129.0, \mathrm{CH}$ & $129.1, \mathrm{CH}$ \\
\hline $4^{\prime}$ & 127.2, CH & $127.4, \mathrm{CH}$ & 127.2, CH \\
\hline
\end{tabular}

Table 3 The inhibition rates of compounds 1, 4-9 against LAG3/ MHC II and LAG3/FGL1 at a concentration of $50 \mu \mathrm{M}$

\begin{tabular}{lcc}
\hline & LAG3/MHC II (\%) & LAG3/FGL1 $(\%)$ \\
\hline $\mathbf{1}$ & 82.41 & 83.94 \\
$\mathbf{4}$ & 55.72 & 24.90 \\
$\mathbf{5}$ & 85.32 & 79.11 \\
$\mathbf{6}$ & -6.96 & 2.66 \\
$\mathbf{7}$ & 82.65 & 92.70 \\
$\mathbf{8}$ & 78.93 & 92.49 \\
$\mathbf{9}$ & 77.42 & 58.36 \\
\hline
\end{tabular}

Table 4 The $\mathrm{IC}_{50}$ values $(\mu \mathrm{M})$ of compounds $\mathbf{1 , 5}, \mathbf{7}, \mathbf{8}$ against LAG3/ MHC II and LAG3/FGL1

\begin{tabular}{lll}
\hline & LAG3/MHC II & LAG3/FGL1 \\
\hline $\mathbf{1}$ & 4.74 & 11.78 \\
$\mathbf{5}$ & 3.18 & \\
$\mathbf{7}$ & 2.37 & 4.39 \\
$\mathbf{8}$ & 2.58 & 7.45 \\
\hline
\end{tabular}

Acknowledgement This project was supported financially by the National Natural Science Foundation of China (No. 21778027) and the Natural Science Foundation of Gansu Province (No. 18JR4RA003).

\section{Compliance with Ethical Standards}

Conflict of interest The authors declare that they have no conflict interest.

Open Access This article is licensed under a Creative Commons Attribution 4.0 International License, which permits use, sharing, adaptation, distribution and reproduction in any medium or format, as long as you give appropriate credit to the original author(s) and the source, provide a link to the Creative Commons licence, and indicate if changes were made. The images or other third party material in this article are included in the article's Creative Commons licence, unless indicated otherwise in a credit line to the material. If material is not included in the article's Creative Commons licence and your intended use is not permitted by statutory regulation or exceeds the permitted use, you will need to obtain permission directly from the copyright holder. To view a copy of this licence, visit http://creativecommons.org/licenses/by/4.0/.

\section{References}

1. K. Scherlach, D. Boettger, N. Remme, C. Hertweck, Nat. Prod. Rep. 27, 869-886 (2010)

2. E. Skellam, Nat. Prod. Rep. 34, 1252-1263 (2017)

3. W.B. Han, Y.J. Zhai, Y. Gao, H.Y. Zhou, J. Xiao, G. Pescitelli, J.M. Gao, J. Agric. Food Chem. 67, 3643-3650 (2019)

4. Z. Shang, R. Raju, A.A. Salim, Z.G. Khalil, R.J. Capon, J. Org. Chem. 82, 9704-9709 (2017)

5. Z.M. Chen, H.P. Chen, Y. Li, T. Feng, J.K. Liu, J. Antibiot. 68 , 23-26 (2015)

6. J.F. Wang, Z. Wang, Z.R. Ju, J.T. Wan, S.R. Liao, X.P. Lin, T.Y. Zhang, X.F. Zhou, H. Chen, Z.C. Tu, Y.H. Liu, Planta Med. 81, $160-166(2015)$

7. X.Q. Xin, Y. Chen, H. Zhang, Y. Li, M.H. Yang, L.Y. Kong, Fitoterapia 132, 53-59 (2019)

8. X. Pang, J.Y. Zhao, X.M. Fang, T. Zhang, D.W. Zhang, H.Y. Liu, J. Su, S. Cen, L.Y. Yu, J. Nat. Prod. 80, 2595-2601 (2017)

9. X.S. Huang, D.X. Zhou, Y. Liang, X.B. Liu, F. Cao, Y.Y. Qin, T.X. Mo, Z.L. Xu, J. Li, R.Y. Yang, Nat. Prod. Res. 1-8 (2019)

10. Y. Xu, B.P. Bashyal, M.X. Liu, P. Espinosaartiles, J.M. Uren, A.E. Arnold, A. Gunatilaka, Nat. Prod. Commun. 10, 1655-1658 (2015)

11. Y.N. Liu, Q.F. Ruan, S.Q. Jiang, Y. Qu, J.Y. Chen, M. Zhao, B. Yang, Y.X. Liu, Z.X. Zhao, H. Cui, Fitoterapia 137, 104187 (2019) 
12. F. Song, S.H. Wu, Y.Z. Zhai, Q.C. Xuan, T. Wang, Chem. Biodivers. 11, 673-694 (2014)

13. S.E. Helaly, B. Thongbai, M. Stadler, Nat. Prod. Rep. 35, 9921014 (2018)

14. Q. Zhang, J. Xiao, Q.Q. Sun, J.C. Qin, G. Pescitelli, J.M. Gao, J. Agric. Food Chem. 62, 10962-10969 (2014)

15. J.C. Chang, G. Hsiao, R.K. Lin, Y.H. Kuo, Y.M. Ju, T.H. Lee, J. Nat. Prod. 80, 38-44 (2017)

16. Y.M. Zhao, P.M. Gu, H.J. Zhang, Q.W. Zhang, C.A. Fan, Y.Q. Tu, F.M. Zhang, J. Org. Chem. 74, 3211-3213 (2009)

17. Q.W. Zhang, K. Xiang, Y.Q. Tu, S.Y. Zhang, X.M. Zhang, Y.M. Zhao, T.C. Zhang, Chem. Asian J. 7, 894-898 (2012)

18. V. Gandhi, W. Plunkett, J.E. Cortes, Clin. Cancer Res. 20, 17351740 (2014)

19. H.C. Puhr, A. Ilhan-Mutlu, ESMO Open 4, e000482 (2019)

20. L. Barrueto, F. Caminero, L. Cash, C. Makris, P. Lamichhane, R.R. Deshmukh, Transl. Oncol. 13, 100738 (2020)

21. E. Ruffo, R.C. Wu, T.C. Bruno, C.J. Workman, D.A. Vignali, Semin. Immunol. 42, 101305 (2019)

22. C.G. Graydon, A.L. Balasko, K.R. Fowke, PLoS Pathog. 15, e1007429 (2019)

23. M. Collin, Expert Opin. Ther. Pat. 26, 555-564 (2016)

24. J. Wang, M.F. Sanmamed, I. Datar, T.T.J. Su, L. Ji, J.W. Sun, L. Chen, Y.S. Chen, G.F. Zhu, W.W. Yin, L.H. Zheng, T. Zhou, T. Badri, S. Yao, S. Zhu, A. Boto, M. Sznol, I. Melero, D.A.A. Vignali, K. Schalper, L.P. Chen, Cell 176, 334-347 (2019)
25. L.P. Andrews, A.E. Marciscano, C.G. Drake, D.A.A. Vignali, Immunol. Rev. 276, 80-96 (2017)

26. C. Solinas, E. Migliori, P.D. Silva, K. Willard-Gallo, Cancers 11, $1213(2019)$

27. W.X. Wang, Z.H. Li, H.L. Ai, J. Li, J. He, Y.S. Zheng, T. Feng, J.K. Liu, Fitoterapia 137, 104253 (2019)

28. W.X. Wang, Z.H. Li, J. He, T. Feng, J. Li, J.K. Liu, Fitoterapia 137, 104278 (2019)

29. H. Minato, T. Katayama, J. Chem. Soc. Perkin. 1, 45-47 (1970)

30. Y.Y. Li, C.H. Lu, Z.Y. Hu, Y.J. Huang, Y.M. Shen, Nat. Prod. Res. 23, 70-76 (2009)

31. H. Xu, W.S. Fang, X.G. Chen, W.Y. He, K.D. Cheng, J. Asian Nat. Prod. Res. 3, 151-155 (2001)

32. Y. Fujii, H. Tani, M. Ichinoe, H. Nakajima, J. Nat. Prod. 63, 132$135(2000)$

33. H. Wei, Y.M. Xu, P. Espinosa-Artiles, M.X. Liu, J.G. Luo, J.M. U'Ren, A. Elizabeth Arnold, A.L. Leslie Gunatilaka, Phytochemistry 118, 102-108 (2015)

34. S. Milhas, B. Raux, S. Betzi, C. Derviaux, P. Roche, A. Restouin, M.J. Basse, E. Rebuffet, A. Lugari, M. Badol, R. Kashyap, J.C. Lissitzky, C. Eydoux, V. Hamon, M.E. Gourdel, S. Combes, P. Zimmermann, M. Aurrand-Lions, T. Roux, C. Rogers, S. Müller, S. Knapp, E. Trinquet, Y. Collette, J.C. Guillemot, X. Morelli, A.C.S. Chem, Biol. 11, 2140-2148 (2016)

35. B. Alpha-Bazin, E. Quéméneur, Anal. Chem. 84, 9963-9970 (2012) 